Anita Varga

Universitetslektor vid Institutionen för pedagogik

Högskolan i Borås

\title{
Talaktsteoretiska perspektiv på skolans litteratursamtal: En studie i lärares lingvistiska strategier
}

\section{Sammendrag}

Dagens samhälle ställer allt högre krav på en muntlig och skriftlig kompetens. Detta reser höga krav på skolan att erbjuda en undervisning som stödjer eleverna att utveckla sådana färdigheter. Forskningen har visat att elever genom textsamtal kan stödjas $i$ att utveckla läsförståelse och även utvecklat metoder för hur sådan undervisning kan bedrivas. (Raphael 1982; Palincsar \& Brown 1984; Baumann, Jones \& Seifert-Kessel 1993; Franzén 1993; 2002; Guthrie et al. 1996; 2004;Sternberg \& Grigorenko 2002a; 2002b; Oszkus 2006; Anmarkrud \& Bråten 2012). Däremot saknas studier som specifikt belyser sådan undervisning utifrån ett språkvetenskapligt perspektiv och undersöker hur lärare med hjälp av sina lingvistiska yttrandehandlingar kan erbjuda eleverna stöd att utveckla läsförmågan. Föreliggande artikel är ett viktigt bidrag inom detta område. Med analysinstrument hämtade ur talaktsteorin analyseras sekvenser ur fyra litteratursamtal i den svenska grundskolans årskurser 6 och 7. Syftet med studien är att identifiera, belysa och analysera kritiska aspekter $i$ samtalet som stödjer eleverna $i$ att utveckla läsförståelse. Studien visar hur lärarna genom sex olika talhandlingar erbjuder eleverna stöd i att identifiera, tillämpa och befästa läsförståelsestrategier, motivera och belägga sina tolkningar, internalisera ett ämnesrelaterat språk $i$ det egna ordförrådet samt utveckla metakognition.

\section{Inledning}

Dagens samhälle ställer allt högre krav på en muntlig och skriftlig kompetens innefattat förmågan att läsa, kritiskt granska, analysera och värdera olika källor, kommunicera via olika genrer och texttyper samt navigera mellan olika språkliga arenor. Detta reser höga krav på skolan att erbjuda en undervisning som stödjer eleverna i att utveckla sådana färdigheter. Samtidigt visar både PIRLS och PISA att svenska skolelevers läsförmåga sjunker i relation till tidigare mätningar, i motsats till bl.a. norska. (Skolverket 2007:305; 2010:352; Skolverket 2012:381). Enligt mätningen 2009 går så mycket som var femte skolelev ur den svenska grundskolan utan att ha uppnått en grundläggande läsförmåga (2010:352, Skolverket 2012; 381). Den senaste mätningen i PISA 
2012 visar dessutom att Sverige har den största uppmätta nedgången sedan år 2000 av samtliga deltagande länder. (Skolverket 2013:398). Detta ökar kraven på skolan att se över sin läsundervisning, både i relation till hur undervisning i läsförståelse bedrivs i de länder där resultaten är fortsatt höga och i ljuset av läsforskningen.

Såväl den nationella som den internationella forskning som intresserat sig för hur elever kan stödjas i sin läsutveckling framhäver den språkliga interaktionens och samtalets betydelse för lärandet (se exempelvis Anmarkrud \& Bråten 2012). I den ämnesdidaktiska forskning som specifikt intresserat sig för skolans läsundervisning i de övre åldrarna - vilket är mitt intresseområde - har textsamtalet ofta stått i centrum, men fokus har inte primärt vilat på läsförståelse. Dessa studier har istället hämtat perspektiv och analysinstrument ur receptionsforskningen och studerat litteratursamtalen utifrån ett klass- och genusperspektiv (Elmfeldt 1997; Malmgren, G 1992; Malmgren, L-G 1997; Molloy 2002; Schmidl 2008), utifrån teorier om litterär socialisation (Linnér \& Malmgren, L-G 1986; Malmgren, G 1992, Thorson 2005) utifrån ett institutionellt perspektiv (Linnér 1984; Thavenius 1991), utifrån ett genreperspektiv (Hultin 2006) samt med fokus på olika läsarter (Tengberg 2011). Den här studien placerar sig dock i det interaktionistiska forskningsfält som intresserat sig för hur samtalet kan användas som stöd för att utveckla elevers läsförståelse. Forskningen har här kunnat visa att elever genom textsamtal kan stödjas i att utveckla läsförståelse och även utvecklat metoder för hur sådan undervisning kan bedrivas. Dessa studier visar att en explicit undervisning i läsförståelsestrategier där läraren dels modellerar för eleverna, dels utmanar dem att ställa frågor, reda ut oklarheter och sammanfatta det lästa stödjer eleverna att utveckla läsförståelsestrategier (Raphael 1982; Palincsar \& Brown 1984; Baumann, Jones \& Seifert-Kessel 1993; Franzén 1993; 2002; Guthrie et al. 1996; 2004; Sternberg \& Grigorenko 2002a; 2002b; Oszkus 2006; Anmarkrud \& Bråten 2012). Några av dessa metoder har introducerats i Sverige (bl. a av Reichenberg 2010, Lundberg \& Reichenberg 2013), men inte förankrats i den svenska skolans undervisning i någon större utsträckning (Reichenberg 2012). Däremot saknas studier som specifikt fokuserar sådan undervisning ur ett språkvetenskapligt perspektiv och belyser hur lärare genom sina lingvistiska strategier kan erbjuda eleverna stöd i att utveckla läsförmågan. Föreliggande artikel är därför ett viktigt bidrag till den ämnesdidaktiska forskning som sysslar med skolans läsundervisning och undervisning genom textsamtal. Här studeras lärares undervisningsstrategier utifrån teorier och analysinstrument hämtade ur språkvetenskapen.

Syftet med studien är att identifiera, belysa och analysera kritiska aspekter i samtalet som stödjer eleverna i att utveckla läsförståelse. Med kritiska aspekter avses situationer i samtalet där tillfällen för eleverna att lära öppnar sig. Fokus vilar på det stöd lärarna erbjuder eleverna genom sina lingvistiska yttrandehandlingar, dvs. genom hur de använder sig av det talade språket för att 
stödja eleverna i att utveckla läsförståelse. Dessa lingvistiska yttrandehandlingar benämns i det följande talhandlingar. Intresset kommer att vila både på talhandlingen i sig och på de färdigheter och förmågor de olika talhandlingarna erbjuder eleverna stöd i att utveckla. Att studera samtalet på en sådan detaljnivå innebär dock att det ömsesidiga meningsutbytet och meningsbyggandet som konstituerar ett samtal endast i mindre grad uppmärksammas. Följande forskningsfrågor bildar utgångspunkt för studien:

- Vilka talhandlingar använder sig lärarna av för att stödja eleverna i att utveckla läsförståelse?

- Vilka specifika förmågor erbjuder dessa talhandlingar eleverna stöd i att utveckla?

Dessa frågor skall besvaras genom en analys av passager ur fyra olika textsamtal i två klasser i årskurs 6 och 7, där det övergripande syftet från lärarnas sida varit att arrangera samtal kring skönlitteratur som stödjer eleverna i att utveckla läsförståelse.

\section{Teoretiska utgångspunkter - talaktsteori}

För att analysera och beskriva de strategier lärarna använder sig av för att stödja eleverna att utveckla läsförståelse kommer jag att ta min utgångspunkt i den lingvistiska filosofin och hämta analysinstrument ifrån talaktsteorin. Talaktsteorin utvecklades av J. L Austin och J. R. Searle och erbjuder verktyg att fokusera på lärarnas lingvistiska strategier i termer av språkliga yttrandehandlingar, vilka kan belysas och analyseras på flera olika nivåer samt utifrån såväl avsändare som mottagare. Detta skapar en möjlighet att på en detaljnivå urskilja vad exakt i lärarnas yttranden som erbjuder stöd för elevernas lärande samt vilka specifika förmågor och färdigheter dessa yttrandehandlingar erbjuder eleverna stöd i att utveckla.

Austin differentierar det språkliga yttrandet i tre olika, men samtidigt verkande akter: den lokutionära, den illokutionära och den perlokutionära akten (Austin 1962, s. 94-107). Med lokutionär akt avses satsen som ett yttrande vilket kan förstås som relationen mellan tecken, dvs. den språkliga utsagan och referent, dvs. den konkreta verklighet tecknet refererar till. Förhållandet mellan tecken och referent är beroende av kontexten och kan bedömas utifrån huruvida det är sant eller falskt. (Austin 1962, s. 100). Satsen "Du står på min fot" som språklig yttrandehandling refererar till ett sakförhållande. Huruvida det är sant eller falskt framgår inte av yttrandet i sig utan är beroende av det sammanhang det yttras i. Den illokutionära akten avser i sin tur syftet med yttrandet och anger 
satsens meningspotential. Austin använder här begreppet "kraft” (force) för att illustrerara yttrandets inbyggda tolkningspotential. Den illokutionära aktens tolkningspotential är inte entydig. Den presenterar sig som en inbjudan till åhöraren att realisera yttrandets betydelse. Också här är det sammanhang yttrandet kommuniceras i avgörande för hur det ska tolkas. Om vi återigen använder ovanstående exempel och tänker oss att det är falskt kan yttrandets illokutionära kraft inbjuda till en tolkning av satsen som ett skämt. Är yttrandet sant genererar det istället en uppfodran: "Kliv av min fot!”. Med en förskjutning från satsens lokutionära nivå till den illokutionära har alltså en tolkningsaspekt tillkommit så att fokus nu vilar på relation mellan tecken, referent och betydelsepotential. Den perlokutionära akten, slutligen, avser den reella effekt yttrandet får på mottagaren (Austin 1962, s. 101). Denna effekt stämmer inte nödvändigtvis överens med den illokutionära kraftens tolkningspotential, även om detta naturligtvis är önskvärt från talarens sida. Om vi igen använder ovanstående exempel skulle den tilltalade helt enkelt kunna vägra att stiga av foten. I en lyckad konversation svarar dock den tilltalade på den illokutionära kraften i yttrandet och realiserar dess betydelsepotential genom att utföra den handling yttrandet uppmanar till.

Den akt jag specifikt kommer att intressera mig för är den illokutionära akten. Detta därför att jag först och främst intresserar mig för yttrandets tolkningspotential - inte de konkreta tolkningar åhörare realiserar vid ett givet tillfälle. En sådan studie, menar jag, gör det möjligt att identifiera talhandlingar som inte uteslutande är kontextbundna utan kan fungera som konkreta och handfasta lingvistiska strategier lärare kan omsätta och använda sig av i den egna undervisningen.

Austin urskiljer fem olika kategorier illokutionära akter inom vars ramar han menar att alla yttranden kan grupperas (Austin 1962, s. 150-163). Han var dock inte riktigt nöjd med dessa utan såg dem som provisoriska i väntan på skarpare distinktioner (Austin 1962, s. 150), något Austin själv inte hann utveckla före sin död. Detta gjordes istället av Searle som kritiserar Austens kategorier på en rad väsentliga punkter, vidareutvecklar kategorierna, justerar benämningen och presenterar en ny gruppering av fem illokutionära akter. Dessa är uppmaningar (directives), dvs. yttranden som uppmanar till ett agerande, påståenden (assertives), dvs. yttranden som syftar till att uttrycka ett faktum, vilket antingen är sant eller falskt, åtagaden (commissives), dvs. yttranden genom vilka talaren förbinder sig själv att agera, uttryckanden (expressives), dvs. yttranden som uttrycker känslor och attityder samt tillkännagivanden (declarations), dvs. yttranden som syftar till att klargöra förändringar (Searle 1979, s. 12-29). Enligt min bedömning är Searles kategorier betydligt mer välpreciserade än Austins och jag har därför valt att använda mig av dessa i min analys. De kommer att användas för att klassificera den typ av yttranden lärarna använder sig av och som utgör ramarna för de specifika talhandlingar som står i centrum för analysen. Varje illokutionär akt utmärks av aktens specifika syfte (illocutionary 
"point" eller "purpose”), vilket inte skall förväxlas med den illokutionära kraften. Det illokutionära syftet för exempelvis kategorin uppmaningar är att få någon att göra något medan den illokutionära kraften varierar beroende av varje enskilt yttrande och manifesterar sig genom ett verb. Så är det exempelvis en skillnad i kraft mellan de två uppmaningarna: "Kan du gå och lägga dig ” och "gå och lägg dig nu". Båda yttrandena hör hemma i kategorin uppmaningar och i båda fallen är syftet att få någon att göra något, men i det första fallet rör det som om en förfrågan och i det andra om en order. De handlingar som avtecknar sig i de illokutionära akterna genom variationen av olika verb kommer jag att kalla talhandlingar, vilket jag signalerade redan inledningsvis. I det första av ovanstående exempel är talhandlingen att efterfråga medan talhandlingen i det senare exemplet är att beordra. Begreppet talhandling kommer att användas för att benämna och beskriva de specifika lingvistiska yttrandehandlingar lärarna använder sig av för att stödja eleverna i att utveckla läsförståelse.

\section{Studiens design}

Empirin är hämtad ifrån ett pågående aktionsforskningsbaserat följeforskningsprojekt, där syftet är att stödja lärarna i att utveckla läsundervisningen i åk 6-9. I studien ingår två klasser och fyra lärare, vilka arbetar i par med var sin klass, samt en specialpedagog. Projektet är longitudinellt och sträcker sig över fyra år, från det att eleverna börjar åk 6 tills de går ut åk 9. Vid projektets början bestod klasserna av elever med varierad läsförmåga. Lärarna har i flera år ägnat sig åt eget fortbildningsarbete, men har sedan projektet startades fått stöd av forskare.

Projektets specifika fokus vilar på hur lärare via textsamtal kring skönlitteratur kan erbjuda elever möjlighet att utveckla läsförståelsestrategier, genrekompetens, metakognition samt ett metaspråk för analys och samtal om texter. En gång varje läsår görs en videoupptagning per klassrum, vilka sedan analyseras och bildar underlag för det fortsatta utvecklingsarbetet. Den empiri som redovisas här är hämtad ur textsamtal i årskurs 6 och 7, där lektionerna varat mellan 40 och 60 minuter. Under dessa lektioner har lärarledda samtal i helklass varvats med samtal i mindre grupper och i par samt med passager då lärarna läser högt för eleverna. I föreliggande artikel utgör de lärarledda och huvudsakligen monologiska passagerna av litteratursamtalen själva ramen. Samtalskontexten som sådan framträder inte så tydligt eftersom det är lärarnas yttrandehandlingar som studeras.

De texter som bildar underlag för samtalen är två romaner och en novell. I åk 6 samtalar lärare 1 och 2 samt deras elever om kapitel sex och sju i romanen Häxfeber (1976) av Leif Esper Andersen. Den andra klassen diskuterar tillsammans med lärare 3 och 4 det inledande kapitlet i Moni Nilssons roman Sejtes skatt (1998). I åk 7 samtalar båda klasserna om Mats Wänblads novell 
Kante (1999). Romanerna har lärarna valt själva medan novellen är vald i samråd med forskaren.

Det empiriska urvalet kan förefalla snävt, men eftersom studien fokuserar kvalitativa aspekter av lärares undervisning som problematiseras i relation till vilka möjligheter som erbjuds att överföra och använda dessa i andra klassrum där samtal kring texter arrangeras får dock resultatet en generaliserbarhet som ger studien en bred räckvidd.

Såväl vid insamlandet av empirin som vid analys av materialet och publicering av studien har vetenskapsrådets etiska regler informationskravet, samtyckeskravet, konfidentialitetskravet och nyttjandekravet iakttagits och efterföljts.

Föreliggande artikel utgör den andra studien som publicerats inom ramen för projektet. (Se även Varga, 2013)

\section{Resultat}

I den empiri som bildar underlag för denna studie urskiljer jag sex olika talhandlingar, vilka används för att stödja eleverna i att utveckla läsförmågan: efterfråga, instruera, förklara, bekräfta, exemplifiera samt tillämpa. Dessa talhandlingar utförs inom ramarna för de tre illokutionära akterna uppmaningar, påståenden och åtaganden. Nedan kommer jag att belysa och analysera hur dessa talakter används av lärarna för att stödja eleverna i att utveckla läsförståelse samt vilka specifika färdigheter och förmågor de olika talakterna främjar utvecklingen av.

\section{Uppmaningar}

Den första illokutionära akt lärarna använder sig av för att stödja eleverna i att utveckla läsförståelse som skall uppmärksammas här är uppmaningar (directives). Den här illokutionära akten används för att utföra två olika stödjande talhandlingar. Dessa är att efterfråga och att instruera. De båda talhandlingarna förenas åt genom den illokutionära aktens syfte (point eller purpose), vilket är att uppmana eleverna att göra något, att utföra något. De skiljer sig dock åt avseende den illokutionära kraften (force), dvs. yttrandehandlingens totala tolkningspotential och därmed avseende det specifika stöd de olika talhandlingarna erbjuder.

\section{Efterfråga}

Den mest frekvent återkommande stödjande strategin som lärarna tillämpar i dessa textsamtal är talhandlingen att efterfråga. Att ställa frågor till eleverna gällande deras läsning och att stödja eleverna i att själva formulera frågor har också forskningen identifierat som ett av de viktigaste inslagen i undervisning som stödjer elever att utveckla läsförståelse (Raphael 1982; Palincsar \& Brown 
1984; Franzén 1993; 2002; Hynds 1992; Oszkus 2006; Lundberg \& Reichenberg 2013) Den här talhandlingen återkommer i många olika varianter och fokuserar flera skilda aspekter både av texten och av elevernas förhållningssätt till den. Med detta fyller efterfrågandet som talhandling också flera olika funktioner i stödet att utveckla läsförmågan. En av de vanligaste funktioner talhandlingen fyller är att de stödjer eleverna i att utveckla metakognition. Ytterligare en viktig funktion talhandlingen att efterfråga fyller är att de stödjer eleverna att identifiera och tillämpa läsförståelsestrategier. Följande passage ur ett textsamtal kring Häxfeber i årskurs 6 visar hur eleverna stödjs i att identifiera och tillämpa strategin att förutspå eller förutsäga kommande händelser. Detta sker genom att läraren tillämpar den illokutionära akten uppmaning, vilken konkretiseras som en efterfrågan. Passagen föregås av att kapitel sex i romanen höglästs. Stycket avslutas med meningen "Vi får besök igen”. Eleverna ombeds sedan att flödesskriva en kort stund utifrån frågorna: "Är det någonting som ni undrar över" eller "Är det något ni vill ta upp” (Lärare 1). När samtalet sedan kommer igång ställer en av eleverna frågan: "Vem var det som kom på slutet?”(Torsten):

Lärare 1 - (citerar): ”Vi får besök igen”. [...]Kommer ni ihåg vad vi sa att det kallas om man ska svara på en sån fråga: "Vem är det som kommer, vem kan de vara?” Vad är det man gör då, minns ni det? Vi hade det på tavlan förra gången. Vad kallas det? (Eleverna räcker upp handen.) Dick?

Dick - Förutsägelse.

Lärare 1 - Ja, jättebra! Förutsägelse (skriver på tavlan). Man förutspår något, förutsäger något. Och den frågan då: ”Vem är det som kommer?” Vad tänker ni? Har ni någon tanke som svar på Torstens fråga: "Vem är det som kommer?” (Citerar texten): ”Vi får besök igen.”

Passagen inleds med att läraren explicit fokuserar på frågans karaktär och frågar eleverna vad detta är för läsförståelsestrategi och hur den skall benämnas: "Vad är det man gör då?[...]Vad kallas det?” (Lärare 1) Den illokutionära kraften i lärarens fråga rymmer en uppmaning till eleverna att identifiera läsförståelsestrategen, vilket Dick gör: ”Förutsägelse”. I denna passage gör också läraren eleverna uppmärksamma på att läsförståelsestrategin bör vara bekant för dem genom att återkoppla till "förra gången" den användes: "minns ni det? Vi hade det på tavlan förra gången.” (Lärare 1) Med detta synliggörs också att detta tillfälle är en rekapitulation av en redan introducerad strategi samt att detta tillfälle kan ses som en del i ett kontinuerligt stöd för eleverna att befästa strategin och internalisera begreppet i det egna ordförrådet. 
En annan viktig funktion talhandlingen att efterfråga fyller i dessa lärares undervisning är att de stödjer eleverna att anlägga perspektiv på texterna och genomföra perspektivförskjutningar. Följande sekvens ur samtalet i årskurs 6 kring Sejtes skatt exemplifierar hur talhandlingen att efterfråga fyller en sådan funktion. Före denna passage har lärarna högläst hela första kapitlet ur romanen. Eleverna har därefter med stöd av lärarna försökt reda ut vilka karaktärerna är, var de befinner sig och när händelserna utspelar sig. Passagen föregås av att en av eleverna lagt fram idén om att de som hittills framstått som goda, dvs. Oella och hennes familj, i själva verket är onda medan Faro skulle vara god. I det följande ser vi hur läraren stödjer eleverna i att genomföra detta perspektivskifte genom att använda talhandlingen att efterfråga:

Lärare 4 - Om vi då tänker så här att Faro inte alls är ond, som Julius säger...Hur skulle det kunna vara då? Vad skulle det kunna vara för nånting i hans berättelse...? Hur skulle den se ut? Petter?

Petter - Äää, den andra, den där motståndsrörelsen eller vad dom nu...dom kanske är spioner eller liknande som ska försöka ta över.

Lärare 4 - Ja, så skulle det kunna vara. Ingrid, hur tänkte du? Ingrid - Om man tog en sån där perspektivförskjutning, eller vad det var, kan ju dom där Oella och dom där också vara onda...Dom kanske vill ta över och härska eller vad de’ är.

Också i detta exempel använder sig läraren av den illokutionära akten uppmaning, vilken även här konkretiseras genom talhandlingen att efterfråga. Den illokutionära kraften i yttrandeakten inbjuder eleverna till att pröva att genomföra perspektivskiftet: ”Om vi då tänker så här att Faro inte alls är ond, som Julius säger...Hur skulle det kunna vara då? Vad skulle det kunna vara för nånting i hans berättelse...? Hur skulle den se ut?”(Lärare 4) En inbjudan både Petter och Ingrid alltså antar och genomför genom att också redovisa sina tolkningsförslag.

En annan vanlig variant av talhandlingen att efterfråga är de återkommande frågor lärarna ställer till eleverna för att stödja dem i att motivera och belägga sina tolkningar. I kommande passage hämtad ur textsamtalet kring Häxfeber i årskurs 6 kan vi se hur denna strategi tillämpas. Efter att de inledande raderna av kapitel sju höglästs föresöker eleverna besvara den tidigare ställda frågan om vem det är som kommer och flera av dem drar slutsatsen att det är en sjukling:

Lärare 2 - [...]Varför tror ni att det är en sjukling då?

Lärare 1 - Vad i det Lärare 2 läste pekar på att det är en sjukling? 
Lärare 2 - En främling. Det står ju inte att det var en sjukling, men vad får er att tro det? Magda?

Magda - För att han hade...en handduk eller vad det nu var, nej ett tygstycke var det ju runt händerna och så svettades han och så...

Passagen inleds med att Lärare 2 uppmanar eleverna att svara på frågan:” Varför tror ni att det är en sjukling då?” (Lärare 2) Också denna fråga hör hemma i den illokutionära akten uppmaningar med dess specifika syfte att uppmana eleverna att utföra något. I detta fall konkretiseras den illokutionära akten i en efterfrågan där den illokutionära kraften rymmer en uppmaning till eleverna att besvara frågan om varför de tror att det är en sjukling. Innan eleverna ges möjlighet till detta ställer lärarna dock ytterligare två frågor. Dels:” Vad i det Lärare 2 läste pekar på att det är en sjukling?” (Lärare 1), vilken riktar blicken mot texten, dels: "En främling. Det står ju inte att det var en sjukling, men vad får er att tro det?” (Lärare 2), vilken klargör att något sjukdomstillstånd inte bokstavligen uttrycks i texten. Den sammantagna illokutionära kraften i dessa tre yttranden rymmer därmed en uppmaning till eleverna att rikta blicken mot textens bokstavliga nivå, dvs. att läsa på raderna, och utifrån dessa tillämpa strategin läsa mellan raderna, samt motivera och belägga tolkningen. I den fortsatta delen av passagen ser vi hur Magda griper sig an detta uppdrag genom att argumentera för sin tolkning utifrån den information som finns i texten.

\section{Instruera}

Ytterligare ett viktigt inslag i dessa lärares undervisning är moment som är instruktionella, dvs. tillfällen då lärarna instruerar eleverna i den eller de läsförståelsestrategier som skall användas. Vikten av att arbeta med tydliga instruktioner i undervisningen är också en av de stödjande strategier som läsforskningen framhäver. (Raphael 1982; Palincsar \& Brown 1984; Franzén 1993; 2002; Oszkus 2006; Anmarkrud \& Bråten 2012; Lundberg \& Reichenberg 2013) Också den stödjande strategin att instruera ingår i gruppen uppmaningar och är i vissa fall skarpare i sin uppfordran än strategin att efterfråga. Till instruktionens genrekonventioner hör en uppmaning - ofta formulerad som en ren imperativsats - där det klart framgår vad som skall göras samt en stegvis beskrivning av hur aktiviteten skall genomföras för att målet slutligen skall uppnås. Att arbeta med instruktionella moment i undervisningen i läsförståelse är ett viktigt stöd för eleverna både genom att den instruktionella talhandlingen pekar ut för eleverna hur de ska gå tillväga för att genomföra strategin och målet för densamma. Nedanstående passage, hämtad ur ett klassamtal kring Kante i årskurs 7, exemplifierar hur ett sådant tillfälle kan se ut. Inför detta samtalstillfälle har lärarna i båda grupperna högläst novellen för eleverna 
samtidigt som eleverna haft texten framför sig. Därefter har eleverna uppmanats att formulera frågor utifrån texten, vilka lärarna samlat in och läst inför det föreliggande samtalet:

Lärare $4-[\ldots]$ Tom, kommer du håg din fråga?

Tom - Näe.

Lärare 4 - ”Jag undrar över Kantes ögon?” Var det inte du som skrev den?

Tom - Jag vet inte.

(Sorls i klassen)

Lärare $4-[\ldots]$ Kan ni inte titta i texten vad som står? Är det någon som kommer ihåg det eller nån som hittar det? [...]Ni ska läsa vad som står på raderna och ni ska tolka vad det kan betyda.

Passagen inleds med att lärare 1 aktualiserar frågan om Kantes ögon som Tom eller någon annan elev ställt. Eftersom fler varit inne på just den frågan blir det sorl i klassen varför lärare 4 avbryter och återtar ordet. I de inledande två meningarna tillämpar läraren den illokutionära akten uppmaningar, realiserad genom talhandlingen att efterfråga. "Kan ni inte titta i texten vad som står? Är det någon som kommer ihåg det eller nån som hittar det?” (Lärare 4) Mot slutet av lärarens yttrande ändras dock tilltalet från den mer ödmjuka formuleringen "kan ni inte" till den mer uppfodrande "Ni ska", vilket också vittnar om ett byte av talhandling så att läraren övergår från att efterfråga till att instruera, dvs. från att efterfråga vad som står i texten och vad detta betyder till att instruera eleverna i hur de ska gå till väga för att ta reda på textens betydelse, samt i vilken ordning de ska genomföra de olika momenten. Textens illokutionära kraft rymmer därmed en uppfordran att följa den instruktion som presenteras genom yttrandet. "Ni ska läsa vad som står på raderna och ni ska tolka vad det kan betyda". (Lärare 4) Att denna instruktion kommer utan någon inledande förklaring, trots att begreppen "läsa på raderna" och "tolka” används skall förstås utifrån det faktum att begreppen är bekanta för eleverna, väl använda i dessa klassrum och därmed inte behöver förklaras. Det instruktionella momentet fungerar här följaktligen som en uppmaning till eleverna att gripa sig an med texttolkningen utifrån en beprövad och inarbetad metod. På så sätt stödjer instruktionen eleverna i att befästa strategierna. 


\section{Påståenden}

Nästa illokutionära akt som skall uppmärksammas här är påståenden (assertives). Den här illokutionära akten används för att utföra tre olika stödjande talhandlingar. Dessa är att förklara, att bekräfta och att exemplifiera. De tre talhandlingarna förenas åt genom den illokutionära aktens syfte, vilket är att uttrycka ett faktum. Detta kan i sin tur problematiseras utifrån huruvida det är sant eller falskt. Denna illokutionära akt sätts i följande exempel fram som en inbjudan/uppfordran att acceptera påståendet som sant. De olika talhandlingarna skiljer sig dock åt avseende den illokutionära kraften, dvs. yttrandehandlingens totala tolkningspotential och därmed avseende det specifika stöd de olika talhandlingarna erbjuder.

\section{Förklara}

Ännu ett centralt och mycket viktigt inslag i dessa lärares undervisning är tillfällen där olika läsförståelsestrategier förklaras för eleverna. Också detta är viktiga stödjande strategier som framhävs av läsforskningen (Raphael 1982; Palincsar \& Brown 1984; Franzén 1993; 2002; Oszkus 2006; Anmarkrud \& Bråten 2012; Lundberg \& Reichenberg 2013) I det material jag haft tillgång till i min studie finns inga moment då en läsförståelsestrategi förklaras för första gången. Däremot finns flera tillfällen då lärarna rekapitulerar tidigare förklarade läsförståelsestrategier genom att så att säga förklara dem igen. Följande sekvens innehåller ett sådant moment. Passagen är hämtad ur den andra klassens textsamtal i årskurs 7 kring Kante och samtalets fokus vilar på hur karaktären Falken skall tolkas. Den övergripande strategin från lärarens sida är här att stödja eleven att motivera sin tolkning genom att belägga den med stöd i texten och redovisa använda läsförståelsestrategier:

Måns - Han är elak.

Lärare 2 - På vilket sätt är han elak?

Måns - Han mobbar.

Lärare 2 - På vilket sätt mobbar han? .....Står det någonstans i texten att han mobbar eller är det någonting som vi förstår av vad Falken gör? Ni vet att läsa på raderna, det som faktiskt står i texten och läsa mellan raderna, sånt som inte står skrivet med ord, men som man med hjälp av det som står skrivet kan lista ut... att så här kan det faktiskt va. Står det att Falken mobbar...att han är elak? 
Passagen tar sin början i att läraren uppmanar eleven att precisera på vilket sätt Falken är elak och mobbar. Den inledande talhandling läraren tillämpar är följaktligen att efterfråga. Detta sker genom att läraren via frågesatser uppmanar eleven att motivera sin tolkning genom konkreta hänvisningar till texten: "På vilket sätt är han elak?[...]På vilket sätt mobbar han?...Står det någonstans i texten att han mobbar eller är det någonting som vi förstår av vad Falken gör?” (Lärare 2) Därefter byter läraren både talakt och talhandling genom att fokusera på de läsförståelsestrategier som krävs för att besvara tidigare ställda frågor och förklara dessa. Med detta ändras också den illokutionära kraften så att yttrandet erbjuder en förklaring av givna läsförståelsestrategier. Samtidigt förflyttar hon fokus från den enskilda eleven till att omfatta hela klassen i sitt tilltal: ” Ni vet att läsa på raderna, det som faktiskt står i texten och läsa mellan raderna, sånt som inte står skrivet med ord, men som man med hjälp av det som står skrivet kan lista ut...att så här kan det faktiskt va.” (Lärare 2) Strategierna benämns också med ett metaspråk, vilket erbjuder eleverna möjlighet att bygga upp ett ämnesrelaterat språk för att sätta ord på sina läsförståelsestrategier. Den inledande kommentaren "Ni vet” signalerar att detta inte är första gången strategierna förklaras och används och synliggör därmed också att detta tillfälle skall förstås som en rekapitulation av tidigare förklarade strategier eleverna förväntas känna till. Detta ger i sin tur bilden av ett klassrum där lärarna genom att repetera tidigare introducerade och förklarade läsförståelsestrategier stödjer eleverna $\mathrm{i}$ att automatisera strategier och internalisera begrepp i det egna ordförrådet.

\section{Bekräfta}

Som vi sett används påståendeakten för att stödja eleverna i att utveckla och befästa läsförståelsestrategier. Därutöver används den för att stödja eleverna i att bli medvetna om vilka strategier de använt samt för att stödja dem i att internalisera begrepp. Detta sker som i ovanstående exempel genom att lärarna förklarar strategier och använder adekvata begrepp. Det sker även genom att lärarna kommenterar elevernas bruk av läsförståelsestrategier, pekar ut för dem att de tillämpat en läsförståelsestrategi när de gjort detta samt benämner använda strategier med ett metaspråk. Detta blir både ett sätt för lärarna att medvetandegöra samtliga elever om den läsförståelsestrategi som just tillämpats och att bekräfta ifrågavarande elevs kunskaper. På så sätt används också denna illokutionära akt, liksom uppmaningsakten för att stödja eleverna i att utveckla metakognition. Den talhandling som skall uppmärksammas här är att bekräfta. Exemplet är hämtat ur ett av textsamtalen kring Kante i årskurs 7 och illustrerar hur denna talhandling används. Passagen föregås av ett försök från elevernas sida att reda ut huruvida karaktären Kärna är en kille eller tjej: 
Hannes - Det är en kille, Kärna.

Lärare 4 - Hur vet du det?

Hannes - Jo, det står här: ”För Kärna, vår idrottslärare, älskar idrott. Han” (pekar i texten)

Lärare 4 - Utmärkt, Hannes!

Lärare 3 - Vet du vad? För att göra så, för att få en uppfattning då, var det en tjej eller kille Kärna då gjorde du något jättebra nu. För då gick du ner i texten och tittade. Står det någonstans och så hittade du då direkt han. Då har du just läst på raderna då. Att det är en han, Kärna. Utmärkt!

Här kan vi alltså se hur en av eleverna besvarar frågan om huruvida Kärna är en tjej eller kille samt hur lärare 4 uppmanar honom att motivera sin tolkning. Eleven synliggör då sina läsförståelsestrategier genom att med ord och gester illustrera hur han gått tillväga för att nå fram till tolkningen: ”Jo, det står här: 'För Kärna, vår idrottslärare, älskar idrott. Han' (pekar i texten)”(Hannes) Hannes motiverar följaktligen sin tolkning genom att hitta ett klargörande ställe i texten och citera detta. Lärare 3 kommenterar omgående Hannes tillvägagångssätt genom att beskriva detta samtidigt som hon både bekräftar att han tillägnat sig en förtjänstfull strategi och pekar ut funktionaliteten i denna. I detta använder sig läraren av den illokutionära påståendeakten och talhandlingen att bekräfta: "Vet du vad? För att göra så, för att få en uppfattning då, var det en tjej eller kille Kärna då gjorde du något jättebra nu. För då gick du ner i texten och tittade. Står det någonstans och så hittade du då direkt han. Då har du just läst på raderna då. Att det är en han, Kärna. Utmärkt!” (Lärare 3) Det illokutionära syftet här är att klargöra ett faktum, dvs. vad Hannes gjorde medan den illokutionära kraften inbjuder till en tolkning av yttrandet som ett beröm för den utförda handlingen. Den illokutionära akten erbjuder därmed eleven en bekräftelse på legitimiteten i val av läsförståelsestrategi och det förtjänstfulla i tillämpningen av densamma och stödjer honom således i att befästa strategin.

\section{Exemplifiera}

Ytterligare ett viktigt inslag i dessa lärares undervisning i läsförståelse är att arbeta med exempel. Utifrån ett talaktsperspektiv skall denna talhandling definieras som att exemplifiera. Det här sker på flera olika sätt och i flera olika sammanhang med den gemensamma nämnaren att exemplen skapar tydlighet genom att de åskådliggör läsförståelsestrategier - helt i enlighet med påståendeaktens illokutionära syfte. I nedanstående sekvens ur textsamtalet i årskurs 6 kring romanen Sejtes skatt kan vi se hur läraren tillämpar denna 
talhandling. Passagen föregår den tidigare citerade passagen som visar hur lärare 4 stödjer eleverna i att genomföra ett perspektivskifte och visar hur själva idén till detta perspektivskifte presenteras av en av eleverna:

Julius - Jag vill inte göra det, men jag måste ju krångla till det lite. Tänk om det är Faro som är god och dom som är onda.

Lärare 4 - Underbart!

Lärare 3 - Vet du vad du gjorde nu, precis då va? Du gjorde någonting som heter perspektivförskjutning. Alltså man ändrar perspektiven. (Riktar sig till klassen)Kommer ni ihåg när vi höll på å läsa Törnrosa tillsammans. Lärare 4 hade en grupp borta i klassrummet och jag hade en grupp här. Och då gjorde vi också detta som Julius talade om med Törnrosa och den här tolfte, eller vad blir det, trettonde féen. Ja, att vi faktiskt vände det och gjorde det till hennes historia, Törnrosa, kommer ni ihåg det?

Här ser vi hur lärare 3 tillämpar en illokutionär påståendeakt vars illokutionära kraft genom talhandlingen att exemplifiera erbjuder åhörarna en förklaringsmodell. Detta sker genom att läraren återkopplar till ett tidigare undervisningssammanhang där eleverna tillämpat ett perspektivskifte och använder det som exempel för att illustrera vad ett perspektivskifte är. Genom att återkoppla till ett tidigare undervisningstillfälle och en text eleverna arbetat med stödjer hon även eleverna i att aktivera sin förförståelse, vilket ytterligare stärker exemplets potential som förklaringsmodell.

\section{Åtaganden}

\section{Tillämpa}

Den sista stödjande talhandling som skall uppmärksammas här är att tillämpa och syftar helt enkelt på lärarnas eget tillämpande av läsförståelsestrategier. Att själva tillämpa läsförståelsestrategier och så att säga modellera dessa är en metod som lyfts fram av forskningen som en viktig stödjande strategi i undervisningen i läsförståelse (Palincsar \& Brown 1984; Franzén 1993; 2002; Oszkus 2006; Anmarkrud \& Bråten 2012). Detta kan ske både explicit och implicit. Dels genom att lärarna före tillämpandet explicit klargör för eleverna att en läsförståelsestrategi skall synliggöras genom egen tillämpning från lärarens sida, dels genom att lärarna helt enkelt tillämpar olika läsförståelsestrategier i det pågående samtalet med eleverna och med detta använder sig själv som exempel. Den här talhandlingen har klara beröringspunkter med den föregående talhandlingen att exemplifiera. I båda fall 
rör de sig om att använda exempel som ett verktyg för att stödja eleverna i att utveckla läsförståelse. Skillnaden ligger i hur dessa exempel konstrueras, vilket är kopplat till val av illokutionär akt. Medan den förra talhandlingen yttras inom ramarna för den illokutionära påståendeakten yttras den senare genom akten åtaganden (commissives), dvs. yttranden genom vilket talaren förbinder sig själv att agera. Det illokutionära syftet med ett åtagande är att klargöra att talaren själv står för utförandet, medan den illokutionära kraften i talhandlingen att tillämpa erbjuder ett exempel på hur ifrågavarande handling skall utföras. Detta sker genom att lärarna konstruerar sig själva som exempel och modellerar strategin. Därmed sätts handlingen fram som en inbjudan till en tolkning eleverna förväntas realisera, memorera och i framtiden imitera.

I det följande kan vi se hur en av lärarna konstruerar sig själv som exempel och modellerar en strategi för eleverna. Detta genom att problematisera och ifrågasätta klassens kollektiva tolkning av romanens tidsperspektiv samt föreslå en helt annan tolkning. Med detta genomför hon också ett perspektivskifte som uppmanar eleverna att granska textens strategier utifrån ett helt annat perspektiv. Den här passagen, som är hämtad ur samtalet om Sejtes skatt, kommer rent kronologiskt före de båda tidigare citerade passagerna ur detta samtal:

Lärare 3 - Får jag fråga en sak? Vad händer om ni istället tänker så här att ni vänder på det? Hur vet ni att det är förr i tiden? Varför kan det inte vara precis tvärtom? Att det är framtid?

Julius - Nu krånglar du bara till det.

I den passage som föregår ovanstående citat har lärarna via frågor och följdfrågor stöttat eleverna att komma fram till en tolkning av när berättelsen utspelat sig. Via textens strategier har eleverna lyckats tidsbestämma den till ca 500 år tillbaka i tiden. Textens strategier är dock vaga och dubbelbottnade, vilket öppnar upp för ett ifrågasättande. I ovanstående passage ser vi hur Lärare 3 byter talhandling från att stödja och vägleda till att ifrågasätta elevernas tolkning. Med detta genomför hon också ett perspektivskifte som uppmanar eleverna att granska textens strategier och sin egen tolkning. Samtidigt agerar hon modell och förevisar ett sätt att läsa som går ut på att kritiskt granska text samt ifrågasätta givna tolkningar genom att anlägga nya perspektiv på texten. Som vi kan se blir den första kommentaren från en elev: "Nu krånglar du bara till det": (Julius) En stund senare kan vi dock se hur samme elev "krånglar till det” med hjälp av samma läsförståelsestrategi som Lärare 3 använder ovan: "Jag vill inte göra det, men jag måste ju krångla till det lite. Tänk om det är Faro som är god och dom som är onda.” (Julius) Som framgått tidigare har klassen arbetat med perspektivförskjutningar tidigare och fått undervisning i detta. Lärarens eget tillämpande av strategin kan ses som ytterligare ett sätt att stödja 
eleverna i att internalisera den medan elevens tillämpande av densamma kan ses som ett uttryck för att det återkommande arbetet med strategin skapat ett sådant stöd att han självständigt kan använda den.

\section{Diskussion}

I föreliggande artikel studeras lärares lingvistiska undervisningsstrategier med hjälp av verktyg hämtade ur talaktsteorin (Austin, 1962; Searle, 1979). Dessa analyseras utifrån den illokutionära akten, dvs. utifrån yttrandet som en inbjudan till tolkning och uttydning. Detta samtidigt som de konkreta exemplen också stundtals visar hur eleverna - helt i enlighet med yttrandets illokutionära kraft svarar på yttrandets inbjudan.

Studien visar hur lärarna erbjuder eleverna stöd genom att använda tre olika illokutionära akter; uppmaningar, påståenden och åtaganden, vilka konkretiseras genom sex olika talhandlingar; att efterfråga, att instruera, att förklara, att bekräfta, att exemplifiera och att tillämpa. Dessa talhandlingar erbjuder eleverna stöd i att själva identifiera, tillämpa och befästa läsförståelsestrategier, motivera och belägga sina tolkningar, internalisera ett ämnesrelaterat språk i det egna ordförrådet samt utveckla metakognition. Detta är förmågor som ingår i en utvecklad läskompetens och som eleverna måste bemästra både för att ta sig vidare inom utbildningssystemet och för att kunna möta de krav som ställs på individen i dagens samhälle.

Vad gäller studiens empiri är det naturligtvis relevant att ifrågasätta det begränsade urvalet samt resa frågor om exemplens generaliserbarhet. Genom att huvudsakligen fokusera den illokutionära akten ges en möjlighet att lyfta lärarnas kontextbundna yttrandehandlingar till en generell nivå och identifiera talhandlingar som rymmer en - förvisso kulturellt och socialt kodad tolkningspotential som erbjuder eleverna stöd i att utveckla läsförmågan. Det är också här talaktsteorin blir ett så värdefullt analysverktyg för studier av yttranden som ingår i både dialogiska och monologiska passager av samtal. Valet av metoden gör det dock möjligt att identifiera, belysa, problematisera och benämna lingvistiska strategier som går att överföra, anpassa och använda i andra klassrum där litteratursamtal arrangeras. På så sätt kan begrepp hämtade ur talaktsteorin även användas som ett metaspråk för verksamma lärare både för att analysera och diskutera den egna undervisningen och som ett didaktiskt verktyg att planera undervisning som stödjer eleverna i att utveckla läsförmågan. Resultatet ifrån studien får därmed en generaliserbarhet och en räckvidd som sträcker sig bortanför det konkreta undervisningssammanhang empirin är hämtad ifrån och har därför hög relevans såväl för läsforskningen som för verksamma lärare som arbetar med textsamtal på alla stadier i den svenska grundskolan. 
En intressant fråga är då vilka perspektiv som öppnar sig genom studien? Här finns möjligheter dels att använda talhandlingar som ett undervisningsredskap i mer 'spontana' eller svagt inramade textsamtal. Dels att utforska hur talaktsteorin som analysredskap och didaktiskt verktyg kan integreras med redan utvecklade metoder som stödjer elever i att utveckla sin förmåga att läsa och samtala om texter. (Raphael 1982; Palincsar \& Brown 1984; Baumann, Jones \& Seifert-Kessel 1993; Franzén 1993; 2002; Guthrie et al. 1996; 2004; Sternberg \& Grigorenko 2002a; 2002b; Oszkus 2006; Anmarkrud \& Bråten 2012). Vad gäller samtalet specifikt skulle talaktsteorin kunna kombineras med de metoder som utvecklats för att stödja elever i att utveckla förmågan att föra den typ av kritiskt granskande, utforskande och kunskapsbyggande samtal Mercer benämner "exploratory talk" (Mercer, 1996; se också ex. Rojas-Drummond \& Mercer, 2003 och Rojas-Drummond \& Peon Zapata, 2004). Talhandlingar som t.ex. att efterfråga, att förklara, att motivera, att exemplifiera och att bekräfta är redan nu möjliga att urskilja i de verktyg som används i samband med undervisning i exploratory talk. Begreppet talhandling, som till skillnad från övriga begrepp i Austins och Searles terminologi är ett begrepp som torde fungera utmärkt i en skolkontext, skulle här kunna användas som ett metaspråk också för eleverna. På så sätt skulle eleverna kunna erbjudas ytterligare stöd i att utveckla och internalisera samtalsstrategier samt stödjas i att utveckla ett metaperspektiv på sitt eget sätt att förhålla sig till hur mening ges och tas i samtal. Det skulle vara intressant att studera effekterna av sådan undervisning.

\section{Referenser}

Anmarkrud, Ö. \& Bråten, I. (2012). Naturally-Occurring Comprehension Strategies Instruction in $9^{\text {th }}$-Grade Language Arts Classrooms. Scandinavian Journal of Educational Research, 56(6), 591-693.

Austin, J. L. (1962). How to do things with words. New York: Oxford University Press.

Baumann, J.F.,et al. (1993). Using think alouds to enhance children's comprehension monitoring abilities. The Reading Teacher, 47(3), 184-193.

Elmfeldt, J (1997). Läsningens röster: om litteratur, genus och lärarskap. Diss. Lund:Lunds universitet.

Franzén, L. (1993). Att "läsa mellan raderna": en studie över goda läsare i åk 5 och deras förmåga att göra inferenser samt några inferensträningsmetoder för svaga läsare. Malmö: Lärarhögsk., Institutionen för pedagogik och specialmetodik.

Franzén, L (2002). Att träna inferenser - teori och träningsprogram. Solna: Ekelunds.

Guthrie, J. T. et al. (1996). Growth of literacy engagement: Changes in motivations and strategies during concept-oriented reading instruction. Reading Research Qarterly, 31,306-332.

Guthrie, J. T., et al. (2004). Increasing reading comprehension and engagement through concept-oriented reading instruction. Journal of Educational Psychology, 96, 403-423.

Hultin, E (2006). Samtalsgenrer i gymnasieskolans litteraturundervisning:en ämnesdidaktisk studie. Diss. Örebro: Örebro universitet, 2006. 
Hynds, S. (1992). Challenging Questions in the Teaching of Literature” I J. Langer (red) Literature Instruction: A Focus on Student Response, s.78-100.

Linnér, B. (1984). Litteratur och undervisning: om litteraturläsningens institutionella villkor. Diss.Lund:Lundsuniversitet.

Linnér, B. \& Malmgren, L-G. (1986). Svenska läsare. Lund: Studentlitteratur.

Lundberg, I \& Reichenberg, M. (2013). Development of reading comprehension among adolescents with mild intellectual disabilities - An intervention study. Scandinavian Journal of Educational Research. (57:1, 89-100)

Malmgren, G. (1992). Gymnasiekulturer: lärare och elever om svenska och kultur. Diss. Lund: Lunds universitet.

Malmgren, L-G. (1997). Åtta läsare på mellanstadiet: litteraturläsning i ett utvecklingsperspektiv. Lund:Studentlitteratur.

Mercer, N. (1996). The Quality of Talk in Children's Collaborative Activity in the Classroom. Learning and Instruction, 6(4), 359-377.

Molloy, G. (2002). Läraren, litteraturen, eleven: en studie om läsning av skönlitteratur på högstadiet. Diss. Stockholm: Lärarhögskolan.

Oczkus, L. D. (2003). Reciprocal teaching at work: strategies for improving reading comprehension. Newark, DE: International Reading Association.

Palincsar, A. S. \& Brown, A. L. (1984). Reciprocal teaching of comprehensive-fostering and comprehension-monitoring activities. Cognition and Instruction, I, 117-175.

Raphael, T. E. (1982) Teaching children Question-Answering Strategies. The Reading Teacher 36(2), 186-191.

Reichenberg, M. (2010). Elever i gymnasiesärskolan läser och samtalar kring lättlästa texter. I Skjeldbred, D \& Aamotsbakken, B (red.), Faglig lesing i skole og barnehage [Students at upper secondary special school talks about texts], s.97-121. Oslo:Novus forlag.

Rojas-Drummond, S \& Mercer, N. (2003). Scaffolding the development of effective collaboration and learning. International Journal of Educational Research 39, 99-111.

Rojas-Drummond, S \& Peon Zapata, M . (2004). Exploratory Talk, Argumentation and Reasoning in Mexican Primary School Children. Language and Education, 18:6, 539557.

Searle, J. R. (1979). Expression and meaning: studies in the theory of speech acts. Cambridge: Cambridge University Press.

Schmidl, H. (2008). Från vildmark till grön ängel: receptionsanalyser av läsning i åttonde klass. Diss. Uppsala:Uppsala universitet, 2008.

Skolverket (2007). PIRLS 2006. Läsförmågan hos elever i årskurs 4 - i Sverige och i världen. Rapport 305. Stockholm: Skolverket.

Skolverket (2013). PISA 2012. 15-åringars kunskaper i matematik, läsförståelse och naturvetenskap. Rapport 398. Stockholm: Skolverket.

Skolverket (2010). Rustad att möta framtiden? PISA 2009 om 15-åringars Läsförståelse och kunskaper i matematik och naturkunskap. Rapport 352. Stockholm: Skolverket.

Skolverket (2010).Texter, textuppgifters och undervisningens betydelse för elevers läsförståelse. Fördjupad analys av PIRLS 2006. Stockholm: Skolverket.

Sternberg, R. J. \& Grigorenko, E. L. (2002a). An evaluation of teacher training for triarchic instruction and assessment. Technical Report for the National Science Foundation, July 2002.

Sternberg, R. J \& Grigorenko, E. L. (2002b). An evaluation of teacher training for triarchic instruction and assessment. Paper presented at the annual IERI Grantee Meeting, Washington, DC.

Tengberg, M. (2011). Samtalets möjligheter: om litteratursamtal och litteraturreception i skolan. Diss. Göteborg: Göteborgs universitet. 
Thavenius, J. (1991). Klassbildning och folkuppfostran: om litteraturundervisningens traditioner. Stockholm: B. Östlings bokförlag Symposion

Thorson, S. (2005). Den dubbla receptionen: om litteratursamtal mellan elever och deras svensklärare. Göteborg: Litteraturvetenskapliga institutionen, Göteborgs universitet.

Varga, A (2013). Metakognitiva perspektiv på skolans litteratursamtal: Hur kan elever stödjas i att utveckla metakognition via samtal om skönlitteratur? Didaktisk Tidskrift, Vol 23, No. I, 493-512. 